\title{
Påtalebegjæring ved brudd på kravet om forsvarlig helsehjelp
}

\begin{abstract}
Sammendrag
Bakgrunn. Statens helsetilsyn kan begjære påtale mot helsepersonell og anmode om påtale mot virksomheter, her felles omtalt som «begjæring». Formålet med denne undersøkelsen var å finne ut hva som skal til for at Statens helsetilsyn begjærer påtale mot leger og/eller virksomheter for brudd på forsvarlighetskravet, hvor ofte det skjer og hva utfallet blir.
\end{abstract}

\begin{abstract}
Materiale og metode. Begjæringer i perioden 1.2. 2002-31. 10.2008 er gjennomgått. Data stammer fra to registre for tilsynssaker. I tillegg ble det innhentet informasjon om utfallet av begjæringene, hovedsakelig fra politi og påtalemyndighet. Antallet tilsynssaker er oppgitt i runde tall, da ulike tellemåter gir litt forskjellig resultat.
\end{abstract}

Resultater. Av totalt ca. 11500 tilsynssaker gjaldt ca. 7700 spørsmålet om hvorvidt leger og/eller virksomheter hadde gitt uforsvarlig helsehjelp. Helsetilsynet i fylkene konkluderte med uforsvarlighet i ca. 2400 saker. Statens helsetilsyn begjærte 19 påtaler i 16 saker $(0,7 \%)$ - ni mot leger og ti mot virksomheter for å ha handlet grovt uforsvarlig. Av begjæringene mot legene endte fire med forelegg, fire ble henlagt og én er ikke avgjort. Åtte virksomheter ble ilagt forelegg, mens to fikk sakene henlagt. Antall påtalebegjæringer for å ha handlet grovt uforsvarlig har vært synkende i perioden.

Fortolkning. Statens helsetilsyn legger i liten grad inn i sin tilsynsrolle det å initiere straffesaker mot leger og virksomheter for uforsvarlighet.

\section{Olav Molven}

molven@diakonhjemmet.no

Diakonhjemmet Høgskole

og

Statens helsetilsyn

Camilla Svenningsen

Statens helsetilsyn

Helsepersonell og virksomheter (helseforetak og kommuner) skal yte «forsvarlig helsehjelp» (1-3). Dette faglige og rettslige kravet innholdsbestemmes i praksis av Statens helsetilsyn $(4,5)$. Ved alvorlige brudd på kravet kan Helsetilsynet, som ledd $\mathrm{i}$ å fremme pasientsikkerheten, gi helsepersonell og virksomheter administrative reaksjoner. Årlig får flere titall leger advarsel og 1-2 mister autorisasjonen pga. brudd på forsvarlighetskravet. Virksomheter kan stanses eller gis pålegg, men det skjer i praksis nesten aldri - fordi virksomhetene retter seg etter de varslene som regelmessig meddeles dem på forhånd. Ved svært alvorlige brudd på forsvarlighetskravet, «forsett eller grov uaktsomhet», kan påtalemyndighet og domstoler også ilegge helsepersonell og virksomheter straff (6-8).

Vanligvis er straffbare handlinger undergitt offentlig påtale. Påtalemyndigheten forfølger handlingene. I visse tilfeller kan særskilte myndigheter påvirke om det skal tas ut påtale. Når politiet etterforsker handlinger eller forhold som straffbare brudd på kravet om å gi forsvarlig helsehjelp, er helsetilsynet i fylkene og Statens helsetilsyn tillagt en slik rolle. Som hovedregel er det overlatt til Statens helsetilsyn å begjære (be om) påtale $(9,10)$. Ut fra politiets etterforskning og det forberedende arbeidet til helsetilsynet i fylkene skal Statens helsetilsyn ta stilling til om manglene ved helsehjelpen er så alvorlige at påtalemyndigheten bør fremme påtale. Helsetilsynet kan også begjære påtale for andre brudd på helsepersonelloven samt for brudd på lov om alternativ behandling. Ved brudd på andre lover, f.eks. straffeloven, kan de, som alle andre, anmelde helsepersonell og virksomheter.

Denne studien er både kvantitativ og kvalitativ. Kvantitativt ønsket vi for det første å kartlegge hvor ofte Statens helsetilsyn begjærer påtale mot leger og/eller virksomheter for brudd på forsvarlighetskravet. For det andre ville vi kartlegge hvilken andel dette utgjør av de sakene der helsetilsynet i fylkene (fra 2012 betegnet Fylkesmannen) ønsker en vurdering av hvorvidt man skal begjære påtale. For det tredje tok vi sikte på å kartlegge om det var noen spesiell utvikling over tid. Vi ønsket også å undersøke påtalemyndighetens videre oppfølging av begjæringene i hvilken grad disse endte med påtale, hvilken straff som gis og om straffereaksjoner fra påtalemyndighet/domstoler og administrative reaksjoner fra Statens helsetilsyn ble kombinert. Vi undersøkte dessuten hvilken andel påtalebegjæringene for uforsvarlighet utgjør av det samlede antall begjæringer om påtale fra Statens helsetilsyn.

Den kvalitative delen av studien omhandler hva som nærmere skal til av mangler ved helsehjelpen før det begjæres påtale.

\section{Materiale og metode}

Materialet består av tilsynssakene som ble avgjort av helsetilsynet $\mathrm{i}$ fylkene og Statens helsetilsyn fra 1.2. 2002 til 31.10. 2008.

Dette er ikke helt de samme sakene, ettersom det vanligvis tar noen måneder fra en sak kommer til Statens helsetilsyn og frem til påtale blir begjært.

Tilsynssakene er identifisert gjennom søk i to databaser: registeret for tilsynssaker ved helsetilsynet i fylkene (RegRot) og registeret for tilsynssaker i Statens helsetilsyn (tilsynssakregisteret). Antall tilsynssaker blir oppgitt i omtrentlige tall, da ulike tellemåter gir litt ulike tall (11). 1.2. $2002 \mathrm{er}$ valgt som starttidspunkt, ettersom sakene fra da er blitt systematisk registrert og er ganske lett tilgjengelige. I praksis forekommer det nesten ikke at påtalemyndigheten reiser påtale uten at saken først har vært til behandling hos Statens helsetilsyn og etter begjæring fra denne instansen.

\section{Hovedbudskap}

- I perioden 1.2. 2002-31.10. 2008 ble det opprettet ca. 7700 saker om uforsvarlig helsehjelp

- I ca. 2400 saker ble helsehjelpen ansett for å være uforsvarlig

- Statens helsetilsyn begjærte påtale i 16 av disse sakene $(0,7 \%)$

- Antall begjæringer rettet mot virksomheter bør vurderes $ø k t$ 


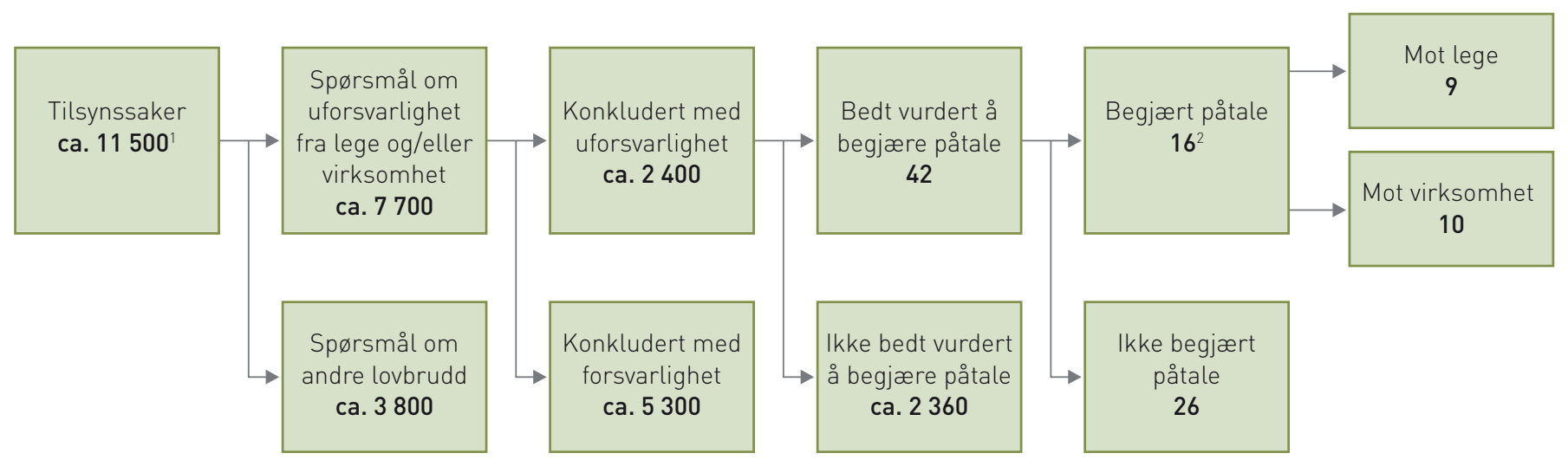

${ }^{1}$ Utover dette ble ca. 1700 saker avgjort ved at partene ble bedt om å ordne opp seg imellom, og gjorde det 216 saker som resulterte i 19 påtalebegjæringer

Figur 1 Antall tilsynssaker der leger og/eller virksomheter har handlet uforsvarlig som endte med påtalebegjæring

Antall tilsynssaker i fylkene, andelen av disse der uforsvarlighet er vurdert og andelen der uforsvarlighet er konstatert fremgår direkte av RegRot. Sakene som har medført at det er bedt vurdert eller blitt begjært påtale, har vi funnet frem til gjennom særskilte søk i tilsynssaksregisteret $\operatorname{og} \mathrm{i}$ arkivet i Statens helsetilsyn på ordene «påtale», «påtalebegjæring» og «begjæring om påtale». Dokumentene i de sakene der det ble begjært påtale pga. uforsvarlighet fra lege og/eller virksomhet, er gjennomgått særskilt for å kunne beskrive nærmere forholdene som medførte påtalebegjæring. Opplysningene som refereres er funnet i dette materialet, med unntak av utfallet av begjæringene. Denne informasjonen er som oftest innhentet fra politi og påtalemyndighet.

Utviklingstrekkene når det gjelder hvem og hva sakene nærmere dreier seg om, er beskrevet ved å dele studieperioden inn i to tidsmessig like lange perioder.

\section{Resultater}

Antall påtalebegjæringer

Av ca. 11500 tilsynssaker gjaldt ca. 7700 spørsmål om hvorvidt virksomheter og/eller leger hadde gitt uforsvarlig helsehjelp. Helsetilsynet i fylkene konkluderte med uforsvarlighet i ca. 2400 av disse. De ba Statens helsetilsyn vurdere å begjære påtale i 42 saker. Påtale ble begjært i 16. Dette er $0,7 \%$ av sakene der det ble konkludert med uforsvarlighet og $38 \%$ av sakene der helsetilsynet i fylkene ba om at det ble vurdert å begjære påtale. De 16 sakene endte med 19 begjæringer - ni gjaldt leger og ti gjaldt virksomheter (fig 1).

I de ca. 3800 sakene som gjaldt andre spørsmål enn uforsvarlighet fra leger og/ eller virksomheter, ble det konkludert med lovbrudd i ca. 2 100. I 40 av disse ba helsetilsynet i fylkene Statens helsetilsyn vurdere å begjære påtale. Begjæring ble fremmet i 30 saker mot 30 personer. 13 av disse gjaldt uforsvarlighet fra annet helseperso- nell enn leger. Det rettslige grunnlaget for alle de 49 begjæringene følger av tabell 1 .

De ca. 11500 sakene medførte, i tillegg til påtalebegjæringene for brudd på helsepersonelloven og lov om alternativ behandling, at tilsynsmyndigheten anmeldte 49 personell for brudd på andre lover. Dette gjaldt primært straffeloven, særlig bestemmelsen i § 193 om seksuell utnytting av pasienter. Ti av disse sakene gjaldt leger. I noen få tilfeller ble det både begjært påtale og innlevert anmeldelse mot lege.

\section{Hva førte til begjæring om påtale?}

Et spekter av klanderverdige forhold førte til at det ble begjært påtale for uforsvarlighet mot leger og virksomheter (tab 2). Disse sakene gjaldt diagnostikk, behandling (herunder pleie og omsorg), forskning og seksuelle krenkinger i behandlingssammenheng. $\mathrm{Ni}$ av de 19 begjæringene, derav to mot leger, gjaldt hendelser der pasienten døde.

For legene var begjæringene oftest knyttet til at de hadde gjort flere alvorlige feil, men omfattet også tilfeller av enkeltstående graverende feil overfor én pasient.

Den faglige svikten som var grunnlaget for påtalebegjæringene mot virksomhetene (tre kommuner og sju helseforetak), gjaldt mangelfulle organisatoriske løsninger og styringssystemer, svikt i ledelse av faglig arbeid, mangler ved bemanningens kvalitet og kvantitet og i noen tilfeller i tillegg klare feil fra helsepersonell. Av sakene finnes ingen tilfeller der det ble begjært påtale mot en virksomhet kun på grunn av grov uaktsomhet fra helsepersonellets side.

\section{Utviklingstrekk}

Helsetilsynet i fylkene ba Statens helsetilsyn om å vurdere å begjære påtale mot til sammen 61 personer og virksomheter i første halvdel av studieperioden og mot $38 \mathrm{i}$ den siste. Begjæring ble fremmet mot henholdsvis 22 og $27 \mathrm{i}$ de to periodene (tab 3, tab 4). Antall henvendelser fra helsetilsynet i fylkene til Statens helsetilsyn om å begjære påtale mot leger eller virksomheter for uforsvarlighet og antall begjæringer om påtale fra Statens helsetilsyn i disse sakene var lavere $i$ annen halvdel av studieperioden enn i første.

Underliggende tall viser at det i studieperioden også innen gruppen «andre brudd» skjedde en endring i hva som førte til begjæring om påtale. I første del av perioden gjaldt begjæringene en stor andel

Tabell 1 Det rettslige grunnlaget for påtalebegjæringene $(n=49)$

\begin{tabular}{|c|c|c|c|}
\hline \multirow[b]{2}{*}{ Rettslig grunnlag } & \multicolumn{3}{|c|}{ Påtaleobjekter } \\
\hline & Virksomhet & Leger & $\begin{array}{c}\text { Annet } \\
\text { personell }\end{array}$ \\
\hline \multicolumn{4}{|l|}{ Brudd på kravet om forsvarlighet } \\
\hline - mangelfull helsehjelp (diagnostikk, behandling, pleie) & 9 & 7 & 5 \\
\hline - intim omgang med og seksuell utnytting av pasienter & 1 & 2 & 8 \\
\hline $\begin{array}{l}\text { Brudd på helsepersonelloven } \S 74 \text { om forbud mot bruk } \\
\text { av beskyttet (profesjons)tittel }\end{array}$ & & $5^{1}$ & 6 \\
\hline Brudd på andre bestemmelser i helsepersonelloven & & 1 & 2 \\
\hline Brudd på lov om alternativ behandling & & & 3 \\
\hline Sum & 10 & $15^{2}$ & 24 \\
\hline
\end{tabular}


annet helsepersonell enn leger som hadde handlet i strid med forsvarlighetskravet.

I andre del var flere begjæringer, både absolutt og relativt sett, knyttet til alternativ behandling og til at personell, herunder tidligere leger, praktiserte på tross av at de var fratatt autorisasjonen.

\section{Strafferettslig utfall}

og administrative reaksjoner

Fire begjæringer mot leger endte med forelegg, fire ble henlagt og én er per juni 2011 ikke avgjort (tab 2). Åtte av de ti virksomhetene ble gitt forelegg, mens for to ble saken henlagt. Tre av de fire legene som ble straffet for uforsvarlighet, fikk i tillegg en administrativ reaksjon. Av virksomheter som ble ilagt straff, var det én som fikk pålegg. De andre mottok brev med kritikk av det som hadde skjedd.

\section{Diskusjon}

Terskelen i praksis for å begjære påtale

Materialet viser at det innledes straffesak mot leger eller virksomheter i under én av hundre tilsynssaker som dreier seg om uforsvarlig helsehjelp. I gjennomsnitt skjer dette tre ganger i året. Dette tyder på at det generelt er liten grunn for leger og virksomheter til å frykte at de vil bli straffeforfulgt etter å ha ytet uforsvarlig helsehjelp.

Straff kan gis når forsvarlighetskravet er brutt med forsett eller etter grov uaktsomhet (sterkt klanderverdig behandling). I praksis blir det nok langt fra begjært påtale i alle slike tilfeller: Årlig får flere titall leger advarsel for å ha handlet uforsvarlig. Terskelen for å gi advarsel er vanligvis at det er handlet nær grovt uaktsomt. Trolig er det i flere enn det i gjennomsnitt drøyt ene tilfellet $i$ året det begjæres påtale at grensen for å ha handlet grovt uaktsomt er overskredet.

Mønsteret for påtalebegjæring mot virksomheter er det samme. Det skal i praksis svært store avvik fra forsvarlighetskravet til før begjæring om påtale fremmes.

I den undersøkte perioden har tilsynsmyndigheten mottatt nærmere tusen meldinger om pasientskader med dødelig utgang (12). Kun ett av tilfellene førte til begjæring om påtale mot lege, og bare

Tabell 2 Forhold som medførte begjæring om påtale for uforsvarlighet helsehjelp, strafferettslig utfall av begjæringen og tilsynsmessig utfall ( $\mathrm{n}$ = 19)

Begjæring om påtale reist mot

Strafferettslig utfall

Tilsynsutfall

Lege for

Mangler knyttet til fødselshjelp

Feil avlesning av et apparat brukt ved diagnostisering

Unnlatt nærliggende differensialdiagnostikk

Unnlatt innhentet informert samtykke, herunder for utvidet kirurgisk inngrep i forbindelse med forskning

Unnlatt innhentet informert samtykke, herunder for utvidet kirurgisk inngrep i forbindelse med forsking

Over lang tid ikke å ha journalført i pasientjournaler og bruk av morfin tatt ut etter narkotikaregnskapet ved legevakt

Snikfotografering og filming av pasienter i forbindelse med gynekologiske unders $ø$ kelser

$\AA$ ha befølt en pasient og onanert med sædavgang i forbindelse med undersøkelse av pasienten

Bruk av injeksjonsteknikk som medførte blodsmitte

\section{Kommunehelsetjenesten for}

Mangel ved systemer som medførte forsinket/mangelfull utredning og behandling ved interkommunal legevakt og svikt i dømmekraften hos flere helsepersonell

Mangelfulle administrative/organisatoriske ordninger knyttet til data som angikk pasientsikkerhet og ikke tatt hensyn til meldinger om svikt ved systemet

Store innskrenkninger i omsorgsnivået for pasient med påfølgende stor risiko

Forelegg kr 50000

Kritikk

Forelegg kr 500000

Kritikk

\section{Spesialisthelsetjenesten for}

Arbeidsbelastningen til overordnet lege

Henlagt $^{2}$

Kritikk

At blodbank leverte blodprodukter ut til transfusjon uten at det forelå bakteriologiske svar på forhånd

At akuttmottak med opptaksområde på vel 200000 personer var bemannet med assistentlege og en turnuslegevikar på vakt, at det var dårlige systemer på mottaket og liten mulighet til hjelp fra bakvakt

Mangel på tilgang til spesialkompetanse i helgen kombinert med legenes manglende aktivitet knyttet til alarmerende symptomer hos pasient

Forelegg kr 100000

Kritikk

Forelegg kr 50000

Kritikk

Organisering, bemanning og drift av AMK-sentral, det fantes nærmest ikke skriftlige prosedyrer for driften og bare var én på vakt

Mangelfull kontroll av at personell som ble ansatt som utnyttet pasient seksuelt hadde autorisasjon som helsepersonell. Sjekket ikke ut fremlagt autorisasjonsbevis mot autorisasjonskontoret

Mangel på kontroll med forskning, unnlatt innhentet informert samtykke, herunder med kirurgisk intervensjon 
noen få til begjæring om påtale mot virksomhet.

Tilsynsmyndighetens sanksjonerende rolle I lovforarbeidene er det gitt lite føringer for når tilsynsmyndigheten bør begjære påtale. Det er ikke sagt om det skal begjæres ved alle grovt uaktsomme og forsettlige brudd eller bare ved de groveste av disse.

Fra ulike hold fremholdes det at tilsynsmyndigheten primært bør ha en veiledende, pasientbeskyttende og sanksjonerende funksjon $(13,14)$. Helsetilsynet i de enkelte fylkene og Statens helsetilsyns syn på vektleggingen av disse ulike funksjonene vil kunne påvirke deres vurderinger av hvor grove lovbrudd som må foreligge.

Riksadvokaten advarer mot «for intens»" straffeforfølging. Det må foreligge et «markant» brudd på forsvarlighetskravet for at man skal kunne begjære påtale mot helsepersonell (9). Dette kan forstås slik at påtale bare bør fremmes når det grovt uaktsomme eller forsettlige lovbruddet innebærer klar fare for dødelig/skadelig utgang.

Når Statens helsetilsyn i gjennomsnitt begjærer påtale mot lege og/eller virksomhet pga. uforsvarlig helsehjelp i omtrent tre saker årlig, kan det sies at tilsynsmyndigheten langt fra har en strafferettslig tilnærming til tilsynssakene. Praksisen samsvarer mest med tenkningen om at tilsynsmyndigheten i liten grad bør innta en sanksjonerende rolle (15), selv om rollen å skulle begjære påtale prinsipielt er tillagt nettopp tilsynsmyndigheten ved alvorlige lovbrudd.

\section{Seksuell utnytting av pasienter}

Når en behandlingssituasjon blir brukt til å etablere en intim relasjon eller direkte utnytte pasienten seksuelt, er det ofte brudd på både helsepersonelloven og straffeloven. Grove tilfeller medfører i praksis påtalebegjæring. I slike tilfeller vurderer Statens helsetilsyn alltid også om forholdet innebærer brudd på straffelovens regler og skal anmeldes (10), og en del forhold blir anmeldt.

\section{Mønsteret i påtalebegjæringene}

Antall begjæringer om påtale i studieperioden utgjør halvparten av antallet der dette blir bedt vurdert. I siste halvdel av perioden er det klart større samsvar enn i den første mellom antall begjæringer og antall tilfeller der det er bedt vurdert å fremme det (tab 3, tab 4).

I de tilfellene der helsetilsynet i fylket ba Statens helsetilsyn vurdere å begjære påtale pga. uforsvarlig praksis i virksomheter, ble påtale likevel vanligvis ikke fremmet. Derimot førte tilfeller der personell hadde opptrådt som helsepersonell uten å ha autorisasjon, svært ofte til begjæring (data ikke vist).

Hva som fører til påtalebegjæring, endret seg i studieperioden. Begjæring om påtale for brudd på andre forhold enn forsvarlighetskravet ble fremmet oftere i siste halvdel

Tabell 3 Henvendelser i perioden 1.2. 2002-31.10. 2008 der helsetilsynet i fylkene ber Statens helsetilsyn å vurdere å begjære påtale ( $n=99)$. I 11 av 53 henvendelser vedrørende uforsvarlighe gjaldt saken både lege og virksomhet. I seks av 46 henvendelser vedrørende andre brudd gjaldt saken både lege eller annet helsepersonell og virksomhet.

\begin{tabular}{|c|c|c|c|}
\hline & & $\begin{array}{l}\text { Første halvdel } \\
\text { av perioden }\end{array}$ & $\begin{array}{l}\text { Siste halvdel } \\
\text { av perioden }\end{array}$ \\
\hline \multirow{4}{*}{$\begin{array}{l}\text { Helsetilsynet i fylkene ber } \\
\text { Statens helsetilsyn vurdere } \\
\text { å begjære påtale }\end{array}$} & Mot leger for uforsvarlighet & 14 & 7 \\
\hline & Mot virksomhet for uforsvarlighet & 25 & 7 \\
\hline & For andre brudd ${ }^{1}$ & 22 & 24 \\
\hline & Sum & 61 & 38 \\
\hline
\end{tabular}

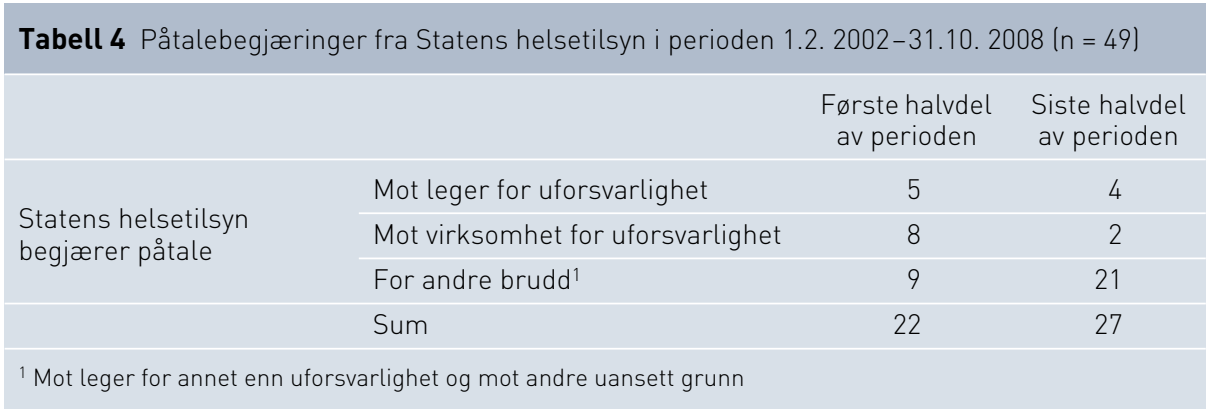

enn i første. Påtale mot virksomheter som hadde handlet i strid med kravet om forsvarlighet, ble begjært klart sjeldnere i den siste delen av perioden.

Statens helsetilsyn har ikke gitt instrukser som tilsier endret praksis overfor virksomhetene. Det kan likevel ha skjedd en holdningsendring i Helsetilsynet. Samhandlingsmønsteret innen tilsynsmyndigheten kan også ha hatt betydning: I studieperiodens første halvdel unnlot Statens helsetilsyn i mange av tilfellene å begjære påtale mot virksomheter. I den andre delen anmodet helsetilsynet i fylkene om vurdering av påtalebegjæring mot klart færre virksomheter. Dette kan skyldes at de anså Statens helsetilsyns praksis i den første halvdelen som et signal om å sende færre tilfeller, noe som førte til at Helsetilsynet i siste halvdel fikk færre tilfeller til vurdering.

\section{For få påtalebegjæringer?}

Antallet påtalebegjæringer mot leger er trolig i overensstemmelse med både Riksadvokatens anbefaling (9) og med uttalelsene i lovforarbeidene om at strafferettslige og administrative reaksjoner til sammen ikke må bli for harde (15).

Det kan tenkes at virksomheter av økonomiske hensyn etablerer prosedyrer og ordninger som i gitte situasjoner gir økt risiko for uforsvarlig hjelp. Strafferettslige sanksjoner kan da ha en preventiv virkning. Den offentlige oppmerksomheten som følger med straff er noe de fleste helseforetak og kommuner ikke ønsker.

Statens helsetilsyn er forpliktet til å begjære påtale mot virksomheter når det er hensiktsmessig, det vil si når det kan ha en preventiv virkning. Plikten henger sammen med at de opptrer som særskilt fagkyndig for påtalemyndigheten, som på sin side er forpliktet til å ta ut påtale dersom dette vurderes som hensiktsmessig (16).

I mange saker har helsetilsynet i fylkene bedt Statens helsetilsyn vurdere å begjære påtale mot virksomheter - uten at så har skjedd. Det kan tyde på at Helsetilsynet er for tilbakeholden med å begjære påtale.

Få påtalebegjæringer mot virksomheter kan henge sammen med at tilsynsmyndigheten anser sakene som for vanskelige å etterforske eller antar at politiet ikke vil prioritere slike saker. Det må likevel kunne forventes at nødvendig etterforskning blir foretatt, eventuelt ved bruk av Kripos (9), og at f.eks. store saker ikke overlates til et lensmannskontor eller et mindre politikammer. Materialet viser da også at påtalemyndigheten henlegger få saker mot virksomheter.

\section{Påtalemyndighetens oppfølging}

Om lag to tredeler av påtalebegjæringene pga. uforsvarlighet fra lege/virksomhet resulterer i at det reises påtale. De øvrige henlegges. De fleste henleggelsene gjelder leger. Årsaken er dels foreldelse, dels bevisets stilling.

Henleggelsene kan ses som et signal om at tilsynsmyndigheten burde undersøkt sakene raskere og bedre. Når henleggelser skjer på grunn av bevisets stilling, kan det også skyldes at politiet ikke kan prioritere å følge opp sakene fra tilsynsmyndigheten. Muntlig har påtalemyndigheten i enkelte saker meddelt dette som et problem og bl.a. vist til kapasitet kombinert med sakenes kompleksitet.

Størrelsen på foreleggene skal reflektere 
handlingenes alvorlighetsgrad, samtidig som det skal tas hensyn til bøtelagtes betalingsevne, jf. straffeloven $\S 27(17,18)$. Beløp opp mot 100000 kroner til en virksomhet er det vanlige. Dette er lite, både ut fra helseforetakenes og kommunenes økonomi og ut fra hva bøtenivået er for virksomheter utenfor helsetjenesten. Det må ikke bli «økonomisk lønnsomt» for helsetjenesten å etablere uforsvarlige ordninger.

\section{Samtidig bruk av straffereaksjoner} og administrative reaksjoner

Begjæring om påtale reises også mot leger som får administrative reaksjoner. Det kan oppleves som urimelig. Formålet med reaksjonene er imidlertid ulike. Mens straffen skal virke avskrekkende, skal de administrative reaksjonene fremme pasientsikkerhet, kvalitet og tillit. For dem som får reaksjonene, er skillet neppe like opplagt.

Leger kan få henlagt en straffesak etter helsepersonelloven, men likevel bli gitt en administrativ reaksjon, jf. tabell 2 . Ved henleggelse på grunn av bevisets stilling skyldes dette at mens kravene for å straffe krever nær sikkerhet for at det er begått lovbrudd, kan administrative reaksjoner gis også når det bare anses som mest sannsynlig at lovbrudd er begått.

\section{Styrker og svakheter}

Studien er den første som viser i hvilken grad tilsynsmyndigheten over tid initierer straff mot leger og virksomheter for brudd på kravet om å gi forsvarlig helsehjelp. Tallene anses å være pålitelige.

En svakhet er at det ikke finnes data som gjør at tallene kan sammenholdes med data for i hvilken grad pasienter, politi og påtalemyndighet helt selvstendig initierer straffesaker.

\section{Oppsummering}

Statens helsetilsyn er tilbakeholden med å begjære påtale mot leger og virksomheter for brudd på forsvarlighetskravet. Antall begjæringer mot virksomheter synes å være for lavt.

Statens helsetilsyn er initiativtaker til undersøkelsen.

\section{Olav Molven (f. 1948)}

er cand. jur. og førsteamanuensis ved Diakonhjemmet Høgskole.

Ingen oppgitte interessekonflikter.

\section{Camilla Svenningsen (f. 1971)}

er cand.jur. og seniorrådgiver i Statens helsetilsyn.

Ingen oppgitte interessekonflikter.

\section{Litteratur}

1. Lov om helsepersonell LOV-1999-07-02-64 § 4.

2. Lov om kommunale helse- og omsorgstjenester m.m. LOV-2011-06-24-30 § 4-1.
3. Lov om spesialisthelsetjenesten LOV1999-07-02-61 § 2-2.

4. Molven O, Holmboe J, Cordt-Hansen K. Forsvarlighetskravet i helsepersonelloven. Tidsskr Nor Lægeforen 2006; 126: 643-4.

5. Molven. O. Kravet til helsepersonell og virksomheter i helsetjenesten om forsvarlighet. Lov og Rett 2009; nr. 1: 3-26.

6. Lov om helsepersonell LOV-1999-02-64 § 67.

7. Andenæs J. Alminnelig strafferett. Oslo: Universitetsforlaget, 1997

8. Almindelig borgerlig straffelov LOV1902-05-22-10 § 48a.

9. Rundskriv fra Riksadvokaten nr. 5/2001. Lov om helsepersonell - påtalemessige direktiver. Oslo: Riksadvokaten, 2001.

10. Rundskriv fra Statens helsetilsyn. IK-2/2008. Retningslinjer for behandling av saker etter helsepersonelloven \$ 67. Oslo: Statens helsetilsyn, 2008.

11. Statens helsetilsyn. Årsmelding 2007. Oslo: Statens helsetilsyn, 2008

12. Årsmelding 2008-2009. Meldesentralen. Oslo: Statens helsetilsyn, 2010

13. Ot.prp. nr. 13 (1998-99). Om lov om helsepersonell mv.

14. Bakke HK. Pasientene trenger et sterkt tilsyn. Tidsskr Nor Lægeforen 2004; 124: 401.

15. Ot.prp. nr. 14 (2001-2002). Om lov om endringer i lov 2. juli $1999 \mathrm{nr} .64$ om helsepersonell mv (helsepersonelloven) og enkelte andre lover.

16. Jensen P. Når er foretaksstraff hensiktsmessig? Lov or Rett 1999; nr. 3: 216-30.

17. Aldmindelig borgerlig straffelov 1902-05-22-10 $\S 27$.

18. Matningsdal M, Bratholm A. red. Straffeloven Kommentarutgave. Første del. Alminnelige bestemmelser. Oslo: Universitetsforlaget, 2003.

Mottatt 21.12. 2010, første revisjon innsendt 7.4. 2011, godkjent 17.11. 2011. Medisinsk redaktør Siri Lunde. 